\title{
Effects of Vitamin E on Reproductive Protection in Pregnant Mice Infected with Pseudorabies Virus (PRV) via Regulating Expression of Toll-Like Receptors (TLRs) and Cytokine Balance
}

\author{
De $\mathrm{WU}^{1,2}$, Xiao-lin $\mathrm{LuO}^{1,2}$, Yan $\mathrm{LIN}^{1,2}$, Zheng-feng $\mathrm{FANG}^{1,2, *}$, Xiao-rong LuO ${ }^{1,2}$, \\ Hai-tao $\mathrm{XU}^{1,2}$ and Wenxian $\mathrm{ZENG}^{3}$ \\ ${ }^{1}$ Key Laboratory for Animal Disease Resistance Nutrition of the Ministry of Education of China, \\ Sichuan Agricultural University, Ya'an, Sichuan, China \\ ${ }^{2}$ Institute of Animal Nutrition, Sichuan Agricultural University, Ya'an, Sichuan, China \\ ${ }^{3}$ College of Animal Science and Technology, Northwest A \& F Univerdsity, Yangling, Shaanxi, China
}

(Received November 24, 2009)

\begin{abstract}
Summary Vitamin E supplement and pseudorabies virus (PRV) infection have a reciprocal role in influencing the maternal immune response, a key determinant of the success or failure of pregnancy. However, it remains unknown whether vitamin E supplement provides protection against PRV-induced failure of pregnancy. This study was therefore conducted to investigate the effect of dietary vitamin E level $(0,75,375,750$ and $1,500 \mathrm{mg} / \mathrm{kg})$ on the reproduction performance, immunity and expression of Toll-like receptors (TLRs) of PRVchallenged mice. The mortality and abortion rate of PRV-challenged mice decreased with the increase in vitamin E consumption. Overall, PBS-injected mice had a higher live embryo number and live litter size than PRV-challenged mice. Both live embryo number and live litter size of PRV-challenged mice increased with increasing vitamin E levels. Vitamin E supplement resulted in decreased concentration of serum IL-2 and IFN- $\gamma$, but increased concentration of serum IL-10. The concentration of serum IgG, IgA and IgM increased with increasing vitamin E levels. In the uterine and embryo mRNA abundance of TLR3, TLR7 and TLR9 was higher in PRV-challenged mice than that in PBS-injected mice fed on the same dosage of vitamin E. The mRNA abundance of embryonic TLR3, TLR7 and TLR9 in PRV-challenged mice decreased with increasing vitamin E levels. Collectively, vitamin E supplement may improve reproductive performance of PRV-challenged mice by attenuating PRV-induced negative effects on the cytokine profile, immunoglobulin synthesis and TLR expression.
\end{abstract}

Key Words vitamin E, pseudorabies virus, Toll-like receptors, cytokines, immunoglobulins

During pregnancy, the balance of T-helper type-1 (Th1) (cell-mediated immunity) and Th2 (humoral immunity) cytokines is characterized by an initial prevalence of Th2 cytokines, followed by a progressive shift toward Th1 predominance late in gestation (1). Th1/ Th2 cytokines play an important role in regulating tolerance to conceptus and supporting pregnancy success. Disturbing the balance of Th1/Th2 has been implicated in infertility, implantation of the embryo, development of the placenta and survival of the fetus $(2,3)$. Th1 cytokines such as interleukin (IL)-2 and interferongamma (IFN- $\gamma$ ) mainly participate in cell immunity and are thought to threaten the maintenance of pregnancy (4). Th2 cytokines such as IL-10 mainly participate in humoral immunity and are considered beneficial for pregnancy and fetal survival (5). Further studies reveal that Th1 and Th 2 cytokines are involved in modulating the expression of Toll-like receptors (TLR) such as TLR3 (6) and subsequent production of immunoglobulin (Ig) i.e. $\operatorname{IgA}, \operatorname{IgM}$ and $\operatorname{IgG}(7)$. The factors that can alter the

\footnotetext{
*To whom correspondence should be addressed.

E-mail: pig2pig@sina.com
}

Th1/Th2 balance may affect embryo survival and pregnancy success $(8,9)$. Therefore, maintaining the Th1/ Th2 balance is essential for successful pregnancy.

Vitamin $\mathrm{E}$ is a family of tocopherols and tocotrienols, and is one of the essential nutrients for immunity (10) and reproduction (11). Vitamin $\mathrm{E}$ is directly involved in pregnancy establishment, and indispensable for the proliferation and/or function of the placenta (12). Growing evidence has indicated that vitamin E supplements can reduce the damage caused by oxidative stress as well as maintaining the integrity of the endometrium (13) and supporting pregnancy (11). In addition, vitamin E supplements can modify Th1/Th2 balance, which could contribute to improved $\mathrm{T}$ cell proliferation and increased $\mathrm{Th} 1 / \mathrm{Th} 2$ ratio as observed in aged mice (14). Vitamin $\mathrm{E}$ is also capable of increasing production of both IFN- $\gamma$ and IL-2 in aged mice after an influenza infection (15), in colorectal cancer patients (16), retroviral infections (17) and coxsackievirus B3 infection in mice (18). Therefore, it is hypothesized that appropriate vitamin $\mathrm{E}$ intake is crucial for maternal immunity and successful pregnancy.

The pseudorabies virus (PRV) is an alphaherpesvirus 
that causes abortion or birth of dead or weak pups in sows (19) and decreased weight of progeny at weaning in mice (20). PRV infection is highly lethal and may represent a sanitary risk for the international trade in porcine embryos because of its origin from blood or semen (19). An immunity-related study indicates that PRVinfected mice have increased synthesis of Th1 inflammatory cytokines (21). Increased Th1 cytokines diminish Th2-mediated immune responses (22), but up-regulate the TLR signaling and thus cause a deleterious hyper-inflammatory state (6), which may account for the failure of pregnancy in PRV-infected mammalians.

Based on the reciprocal role of vitamin E supplement and PRV challenge on the maternal immune response. This study was conducted to determine whether vitamin E supplement could improve reproductive performance in PRV-challenged mice, by attenuating the PRVinduced negative effect on pregnancy with regard to cytokine profile, immunoglobulins synthesis and TLR expression.

\section{MATERIALS AND METHODS}

Mice, diets and experimental design. One hundred and thirty 6-wk-old female Kunming mice (specifiedpathogens free) with a mean body weight of 23.2 $\pm 2.2 \mathrm{~g}$ were purchased from Sichuan Academy of Medical Sciences-Sichuan Provincial People's Hospital Experimental Animal Research Institute [License: SCXK (Chuan) 2004-15]. Mice were housed in cages at 20$25^{\circ} \mathrm{C}$, relative humidity of $55-65 \%$ and $12 \mathrm{~h}$ light/dark cycle throughout the study in a small animal laboratory of Animal Nutrition Institute, Sichuan Agricultural University. The protocol of this study was approved by the Animal Care and Use Committee of Animal Nutrition Institute, Sichuan Agricultural University and was carried out in accordance with the National Research Council's Guide for the Care and Use of Laboratory Animals.

Vitamin E-deficient basal diet was formulated based on AIN-93G (Table 1). Twenty mice were fed on the control diet (containing vitamin $\mathrm{E}$ at $75 \mathrm{mg} / \mathrm{kg}$ ) and the others were fed on a vitamin E-deficient diet to establish a vitamin E deficiency model. After $7 \mathrm{wk}$, venous blood was collected once every $7 \mathrm{~d}$ intra-orbitally from eye sockets. Alpha-tocopherol concentration was determined with high performance liquid chromatography (HPLC). Compared to the control group, the plasma vitamin E concentration of mice fed on the deficient diet significantly decreased (less than $0.5 \mu \mathrm{g} / \mathrm{mL}$ ) with no typical symptoms of vitamin E deficiency for $7 \mathrm{wk}$. This was considered as the successful establishment of vitamin E deficiency model (23). Eighty-nine mice weighing $41.8 \pm 6.5 \mathrm{~g}$ were divided into five groups $(n=16-$ 20 per group) and fed on treatment diets containing different vitamin E levels $(0,75,375,750,1,500 \mathrm{mg} / \mathrm{kg}$, $d l-\alpha$-tocopherol acetate, Sigma, T3376, HPLC $\geq 96 \%$ ). After $3 \mathrm{wk}$ of adaptation, 4 female mice per cage were housed overnight with 2 male Kuming mice. Pregnancy was determined the next morning by the presence of a vaginal plug and this was designated as gesta-
Table 1. Composition and nutrient levels of experimental diets.

\begin{tabular}{lrlr}
\hline \multicolumn{1}{c}{ Ingredients } & $\begin{array}{c}\text { Content } \\
(\%)\end{array}$ & $\begin{array}{c}\text { Nutrition } \\
\text { index }\end{array}$ & $\begin{array}{c}\text { Nutrient } \\
\text { levels }\end{array}$ \\
\hline Cornstarch & 39.80 & $\mathrm{CP}(\%)$ & 17.90 \\
Casein & 20.00 & $\mathrm{DE}(\mathrm{MJ} / \mathrm{kg})$ & 16.50 \\
Gelatinization starch & 13.50 & $\mathrm{Met}(\%)$ & 0.54 \\
Sucrose & 10.00 & $\mathrm{Lys}(\%)$ & 1.47 \\
Soybean oil & 7.00 & $\mathrm{Ca} \mathrm{( \% )}$ & 0.63 \\
Fiber & 5.00 & $\mathrm{AP}(\%)$ & 0.43 \\
Mineral premix ${ }^{1}$ & 3.50 & & \\
Vitamin premix ${ }^{2}$ & 1.00 & & \\
Choline & 0.20 & & \\
(choline chloride 50\%) $_{\text {Total }}$ & 100.00 & & \\
&
\end{tabular}

${ }^{1}$ Provided per kg of diet: Ca 5,000 mg; P 1,561 mg; K 3,600 mg; Na 1,019 mg; Cl 1,517 mg; Mg $510 \mathrm{mg}$; Fe 35 mg; Zn 30 mg; Mn 10 mg; Cu 6 mg; I $0.2 \mathrm{mg}$; Se $0.15 \mathrm{mg}$. Antioxidant (TBH) $20 \mathrm{mg}$.

${ }^{2}$ Provided per kg of diet: VA 4,000 IU; $\mathrm{VD}_{3} 1,000 \mathrm{IU}$; $\mathrm{VK}_{3}$ $0.75 \mathrm{mg} ; \mathrm{VB}_{1} 6.0 \mathrm{mg} ; \mathrm{VB}_{2} 7.0 \mathrm{mg} ; \mathrm{VB}_{6} 6.0 \mathrm{mg} ; \mathrm{VB}_{12}$ $0.02 \mathrm{mg}$; nicotinic acid $30.0 \mathrm{mg}$; D-calcium pantothenate $15.3 \mathrm{mg}$; folic acid $2.0 \mathrm{mg}$; biotin $0.2 \mathrm{mg}$.

tional day 0.5 .

After confirmation of pregnancy, female mice were intraperitoneally injected with $0.5 \mathrm{~mL}$ of PRV solution to offer PRV at $3.5 \times 10^{3} \mathrm{PFU} / \mathrm{g}$ BW. This PRV injection dosage was determined in a preliminary trial and this dosage would affect the brain functions and reproductive functions without being lethal to the injected mice (data is not shown). The control group was intraperitoneally injected with $0.5 \mathrm{~mL}$ of phosphate buffered saline (PBS). PRV or PBS-injected mice were housed separately in temperature-controlled and well ventilated rooms under a 12-h light/dark cycle. All the mice were daily supplied with fresh diets refrigerated at $4^{\circ} \mathrm{C}$ and had free access to water at all times.

Blood sampling and tissue collection. On day 9 of gestation, ten mice per group were fasted for $12 \mathrm{~h}$, blood was collected via intra-orbital bleeding under aerrane anesthesia and centrifuged at 3,000 rpm for $15 \mathrm{~min}$, and serum samples were separated and stored at $-80^{\circ} \mathrm{C}$ until analysis. Brain, liver, uterus and live embryos were collected after $\mathrm{CO}_{2}$ asphyxiation and the data for the collected samples were recorded. Samples for the left and right sides of the uterus and embryos were collected individually. All samples were immediately frozen in liquid nitrogen and stored at $-80^{\circ} \mathrm{C}$ until analyzed.

Mortality and abortion rate. After PRV injection, the number of dead mice and non-pregnant mice in each group was recorded for the calculation of mortality and abortion rate. Abortion number included pregnant (plug-positive) females that yielded no pups and mice miscarriaged on day 9 of gestation. "Successful" pregnancies were those yielding at least one pup (24). Live litter size of each mouse was recorded within $12 \mathrm{~h}$ post parturition.

PRV detection. PCR for detection of viral DNA was 
Table 2. The primer sequences of target genes and house-keeping gene.

\begin{tabular}{|c|c|c|c|}
\hline Genes & Primer sequences $\left(5^{\prime}-3^{\prime}\right)$ & PCR product (bp) & $\begin{array}{c}\text { Genebank accession } \\
\text { number }\end{array}$ \\
\hline TLR3 & $\begin{array}{l}\text { F:CCGCCCTCTTCGTAACTTGACC } \\
\text { R: GCGGCCCGAAAACATCCTT }\end{array}$ & 392 & NM-021297 \\
\hline TLR7 & $\begin{array}{l}\text { F: ACTTCGGCCAGCAGGACCAT } \\
\text { R: AGATTTGGCGGCATACCCTC }\end{array}$ & 203 & NM-133211 \\
\hline TLR9 & $\begin{array}{l}\text { F: CTTGCCACATGACCATTGAG } \\
\text { R:TGTAGTAGCAGTTCCCGTCC }\end{array}$ & 216 & NM-031178 \\
\hline$\beta$-actin & $\begin{array}{l}\text { F: TGCTGTCCCTGTATGCCTCT } \\
\text { R: TTTGATGTCACGCACGATTT }\end{array}$ & 224 & NM-007393 \\
\hline
\end{tabular}

performed using PRV gB-specific primers (forward primer: 5'-ACCCGTACACCGAGTCGTGGCA-3', reverse primer: 5'-CGGCGTCAGGAATCGCATCA-3') (Genebank accession number DQ367438), resulting in a 572 bp fragment. Total DNA was extracted from the brain with a phenol/chloroform method as described (25). Each PCR reaction was performed in a $10 \mu \mathrm{L}$ reaction volume containing $5 \mu \mathrm{L}$ Taq polymerase buffer, $1.6 \mu \mathrm{L}$ dNTP, $0.2 \mu \mathrm{L}$ Taq DNA polymerase (Takara), $0.2 \mu \mathrm{L}$ of each primer $(10 \mu \mathrm{M})$, and $2 \mu \mathrm{L}$ of extracted cDNA. Cycling conditions were as follows: initial denaturation for $5 \mathrm{~min}$ at $95^{\circ} \mathrm{C}$ followed by 30 cycles of denaturation for $1 \mathrm{~min}$ at $95^{\circ} \mathrm{C}$, annealing for $1 \mathrm{~min}$ at $62^{\circ} \mathrm{C}$, extension for $90 \mathrm{~s}$ at $72^{\circ} \mathrm{C}$, and followed by a final extension for $10 \mathrm{~min}$ at $72^{\circ} \mathrm{C}$. PCR products were analyzed by $1 \%$ agarose gel electrophoresis, stained with ethidium bromide, and visualized under UV light. Signals were regarded as positive if the fluorescence intensity exceeded 10 times the standard deviation of the baseline fluorescence (26). Positive results indicated that mice were infectious.

Measurement of $\alpha$-tocopherol concentration. Alphatocopherol in serum, liver and uterus were measured individually according to Hatam et al. (27) and Rupérez et al. (28), using dl- $\alpha$-tocopherol (Sigma, 258024, HPLC $\geq 97 \%$ ) as an external standard. Alpha-tocopherol content was determined after separation by HPLC using a $4.6-\mathrm{mm} \mathrm{C18}$ reverse-phase column with the mobile phase $\left(2 \% \mathrm{H}_{2} \mathrm{O}\right.$ in methanol $)$ delivered at $1.0 \mathrm{~mL} / \mathrm{min}$ at $292 \mathrm{~nm}$.

Determination of serum immunoglobulin concentration. Serum IgG, IgA and IgM concentrations were determined using an Immunity Transmission Turbidimetry kit (MaiKe Technology Corporation, No. 0308061) on a nucleic acid/protein analyzer (Beckman DU-800, USA) according to the manufacturer's instructions. Absorbance was measured at $340 \mathrm{~nm}$.

Determination of IL-2, IL-10, and IFN- $\gamma$ concentration. Serum IL-2, IL-10 and IFN- $\gamma$ concentrations were determined using a mouse enzyme-linked immunosorbent assay (ELISA) kit (R\&D Systems) according to the manufacturer's instructions. All assays were performed in 48-well plates and absorbance was measured at $450 \mathrm{~nm}$ by using an enzyme-labelled meter (Thermo Electron Corporation, Varioskan $\left.{ }^{\mathrm{TM}}\right)$. The levels of IL-2, IL-10 and IFN- $\gamma$ were determined from the standard curve and were expressed as picogram per milliliter.

Detection of mRNA levels of TLR3, TLR7 and TLR9 in uteri and embryos. The left uterus and pooled embryos of the left uterus were used for RNA extraction according to the manufacturer's instructions with TRIzol reagent (Invitrogen, Carlsbad, CA, USA). Reverse transcription (RT) was carried out in a total volume of $10 \mu \mathrm{L}$ containing $2 \mu \mathrm{L} 5 \times$ Prime script TM Buffer, $0.5 \mu \mathrm{L}$ Prime script TM RT Enzyme Mix, $0.5 \mu \mathrm{L}$ Oligo dT Primer $(50 \mu \mathrm{M}), 0.5 \mu \mathrm{L}$ Random hexamer primers (100 $\mu \mathrm{M}), 1 \mu \mathrm{L}$ total RNA, $5.5 \mu \mathrm{L}$ RNase free $\mathrm{ddH}_{2} \mathrm{O}$. The RT reaction was performed at $37^{\circ} \mathrm{C}$ for $15 \mathrm{~min}$ and $85^{\circ} \mathrm{C}$ for $5 \mathrm{~s}$.

Real-Time PCR was performed to analyze TLR3, TLR7 and TLR9 mRNA expression in the uterus and embryos using SYBR Green PCR Mix (TaKaRa, Japan). A total volume of $10 \mu \mathrm{L}$ reaction system contained $5 \mu \mathrm{L}$ SYBR Premix Ex Taq $(2 \times), 0.2 \mu \mathrm{L}$ of each primer (10 $\mu \mathrm{M}), 1 \mu \mathrm{L}$ cDNA and $3.6 \mu \mathrm{L} \mathrm{ddH}_{2} \mathrm{O}$. The primer sequences of TLR3, TLR7, TLR 9 and $\beta$-actin are shown in Table 2.

The PCR reaction was performed as follows: predenaturation at $95^{\circ} \mathrm{C}$ for $1 \mathrm{~min}$, followed by 40 cycles of denaturation at $95^{\circ} \mathrm{C}$ for $5 \mathrm{~s}$, annealing at $60^{\circ} \mathrm{C}$ for $30 \mathrm{~s}$, and extension at $72^{\circ} \mathrm{C}$ for $30 \mathrm{~s}$. Melt curve conditions were $95^{\circ} \mathrm{C}$ for $0 \mathrm{~s}, 50^{\circ} \mathrm{C}$ for $30 \mathrm{~s}$ and $95^{\circ} \mathrm{C}$ for $0 \mathrm{~s}$ (temperature change velocity: $\left.0.5^{\circ} \mathrm{C} / \mathrm{s}\right)$. Real-time PCR analysis was performed on cDNA samples using Quantitect SYBR Green reagent and BioRad Research DNA Engine Opticon System. The comparative threshold cycle method was used to quantify the relative levels of gene expression and was normalized to the housekeeping gene $\beta$-actin. The experiment was repeated three times.

Statistical analysis. Data, except for those presented as percentages, were analyzed by using the one-way ANOVA procedures of the SAS statistical package (V8.1, SAS Institute Inc., Cary, NC). Multiple comparison by Duncan analysis was performed to determine statistical differences between groups. A paired $t$ test was performed to determine differences in hepatic $\alpha$-tocopherol concentration, serum immunoglobulin and cytokine concentrations, TLR mRNA levels, live embryo number and live litter size between the PBS group and the PRV group fed the same dosage of vitamin E. Results were considered significant at $p<0.05$ for all tests and data represent the mean \pm SD of all repeats. Regression anal- 
ysis was applied between vitamin $\mathrm{E}$ levels $\left(x, \times 10^{3} \mathrm{IU} /\right.$ $\mathrm{kg}$ ) and live embryo number $(y)$ on the 9th day of pregnancy. Survival and miscarriage rates were analyzed by the chi-square test.

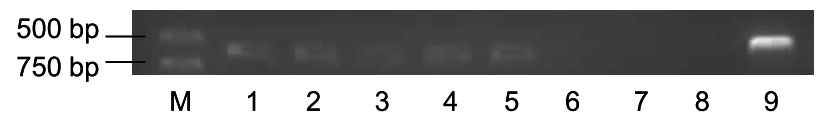

Fig. 1. PCR product of PRV in brain tissue on the 9th day of pregnancy. M, DL2000 marker; 1-5 were the PRV-injected groups fed vitamin $\mathrm{E}$ at $0,75,375,750$ and $1,500 \mathrm{mg} / \mathrm{kg}$ diet, respectively; $6-8$ were the PBSinjected groups fed vitamin $\mathrm{E}$ at 0,75 and $375 \mathrm{mg} / \mathrm{kg}$ diet, respectively; 9 was the positive control.

\section{RESULTS}

PCR confirmation of PRV infection in the brain tissue on the 9th day post-infection

After PRV or PBS intraperitoneal injection, the virus could be detected in the brain tissue due to the brainspecific location of this virus. PRV was able to be detected on the 9th day post-infection in the brain of mice challenged with PRV, whereas no PRV was present in the PBS-treated mice (Fig. 1).

Vitamin E supplements enhanced serum, hepatic and uterine $\alpha$-tocopherol concentration

Effects of dietary vitamin E level on blood, hepatic and uterine $\alpha$-tocopherol concentrations of PRV-

Table 3. Effects of vitamin E supplement on serum $\alpha$-tocopherol concentration in PRV-challenged mice and PBS-treated mice on the 9th day of pregnancy.

\begin{tabular}{|c|c|c|c|c|c|}
\hline Vitamin E level (mg/kg) & 0 & 75 & 375 & 750 & 1,500 \\
\hline Challenged group ${ }^{1}(\mu \mathrm{g} / \mathrm{mL})$ & $2.30 \pm 0.22^{\mathrm{a}}$ & $2.54 \pm 0.18^{\mathrm{b}}$ & $2.75 \pm 0.28^{c}$ & $3.02 \pm 0.12^{\mathrm{d}}$ & $3.08 \pm 0.26^{\mathrm{d}}$ \\
\hline $\operatorname{PBS}_{\operatorname{group}}^{2}(\mu \mathrm{g} / \mathrm{mL})$ & $2.58 \pm 0.21^{\mathrm{a}}$ & $2.62 \pm 0.27^{\mathrm{a}}$ & $3.36 \pm 0.55^{b}$ & & \\
\hline Pair-sample $t$ test $^{3}$ & $p>0.05$ & $p>0.05$ & $p<0.05$ & & \\
\hline
\end{tabular}

\footnotetext{
${ }^{1}$ Data are presented as means \pm SD. Means in the same row with no common superscripts differ significantly $(p<0.05)$ among PRV groups.

${ }^{2}$ Data are presented as means \pm SD. Means in the same row with no common superscripts differ significantly $(p<0.05)$ among PBS groups.

${ }^{3}$ A paired $t$ test was performed to determine differences in serum $\alpha$-tocopherol concentration between the PBS groups and the PRV groups fed on the same dosage of vitamin E. Paired $t$-test $p$ value represented the difference of means within the same column; $p<0.05$ was considered significant.
}

Table 4. Effects of vitamin E supplement on hepatic $\alpha$-tocopherol concentration on the 9th day of pregnancy.

\begin{tabular}{|c|c|c|c|c|c|}
\hline Vitamin E level (mg/kg) & 0 & 75 & 375 & 750 & 1,500 \\
\hline Challenged group ${ }^{1}(\mu \mathrm{g} / \mathrm{g})$ & $45.39 \pm 6.23^{\mathrm{a}}$ & $97.60 \pm 6.48^{\mathrm{a}}$ & $394.67 \pm 57.80^{\mathrm{b}}$ & $640.60 \pm 67.96^{c}$ & $897.07 \pm 68.22^{\mathrm{d}}$ \\
\hline $\operatorname{PBS}_{\operatorname{group}}^{2}(\mu \mathrm{g} / \mathrm{g})$ & $47.91 \pm 4.24^{\mathrm{a}}$ & $213.42 \pm 21.49^{b}$ & $490.14 \pm 65.01^{\mathrm{c}}$ & & \\
\hline Pair-sample $t$ test $^{3}$ & $p>0.05$ & $p<0.05$ & $p>0.05$ & & \\
\hline
\end{tabular}

${ }^{1}$ Data are presented as means \pm SD. Means within a row with no common superscripts differ significantly $(p<0.05)$ among PRV groups.

${ }^{2}$ Data are presented as means \pm SD. Means in the same row with no common superscripts differ significantly $(p<0.05)$ among PBS groups.

${ }^{3}$ A paired $t$ test was performed to determine differences in hepatic $\alpha$-tocopherol concentration between the PBS group and the PRV group fed on the same dosage of vitamin E. Paired $t$-test $p$ value represented the difference of means within the same column; $p<0.05$ was considered significant.

Table 5. Effects of vitamin E supplement on uterine $\alpha$-tocopherol concentration of PRV-challenged mice and PBS-treated mice on the 9th day of pregnancy.

\begin{tabular}{|c|c|c|c|c|c|}
\hline Vitamin E level (mg/kg) & 0 & 75 & 375 & 750 & 1,500 \\
\hline Challenged group ${ }^{1}(\mu \mathrm{g} / \mathrm{g})$ & $0.78 \pm 0.20^{\mathrm{a}}$ & $1.10 \pm 0.17^{b}$ & $1.15 \pm 0.26^{\mathrm{b}}$ & $1.16 \pm 0.27^{\mathrm{b}}$ & $1.50 \pm 0.23^{\mathrm{c}}$ \\
\hline $\operatorname{PBS}_{\operatorname{group}^{2}}(\mu \mathrm{g} / \mathrm{g})$ & $0.82 \pm 0.22^{\mathrm{a}}$ & $1.36 \pm 0.08^{b}$ & $2.08 \pm 0.76^{\mathrm{c}}$ & & \\
\hline Pair-sample $t$ test $^{3}$ & $p>0.05$ & $p>0.05$ & $p<0.05$ & & \\
\hline
\end{tabular}

\footnotetext{
${ }^{1}$ Data are presented as means \pm SD. Means in the same row with no common superscripts differ significantly $(p<0.05)$ among PRV groups.

${ }^{2}$ Data are presented as means \pm SD. Means in the same row with no common superscripts differ significantly $(p<0.05)$ among PBS groups.

${ }^{3}$ A paired $t$ test was performed to determine differences in uterine $\alpha$-tocopherol concentration between the PBS group and the PRV group fed on the same dosage of vitamin E. Paired $t$-test $p$ value represented the difference of means within the same column; $p<0.05$ was considered significant.
} 
Table 6. Effects of vitamin E supplement on mortality and abortion rate of pregnant mice with PRV challenge.

\begin{tabular}{|c|c|c|c|c|c|}
\hline Vitamin E level (mg/kg) & 0 & 75 & 375 & 750 & 1,500 \\
\hline Death number/total number & $5 / 20$ & $3 / 18$ & $2 / 16$ & $2 / 17$ & $1 / 18$ \\
\hline Mortality & $25.0 \%$ & $16.7 \%$ & $12.5 \%$ & $11.8 \%$ & 5. $6 \%$ \\
\hline Abortion number/(total number-death number) & $6 / 15$ & $4 / 15$ & $2 / 14$ & $1 / 15$ & $1 / 17$ \\
\hline Abortion rate ${ }^{1}$ & $40.0 \%{ }^{\mathrm{a}}$ & $26.7 \%$ ab & $14.3 \% \mathrm{ab}$ & $6.7 \%$ ab & $5.9 \%{ }^{b}$ \\
\hline
\end{tabular}

${ }^{1}$ Means in the same row with no common superscripts differ significantly $(p<0.05)$.

Table 7. Effects of vitamin E supplement on the number of live embryos on the 9th day of pregnancy and live litter size.

\begin{tabular}{|c|c|c|c|c|c|c|}
\hline \multicolumn{2}{|c|}{ Vitamin E level (mg/kg) } & 0 & 75 & 375 & 750 & 1,500 \\
\hline \multirow[t]{3}{*}{ Live embryos } & Challenged group ${ }^{1}$ & $9.33 \pm 2.07^{\mathrm{a}}$ & $12.40 \pm 1.95^{\mathrm{b}}$ & $13.40 \pm 1.95^{\mathrm{b}}$ & $14.80 \pm 2.17^{\mathrm{b}}$ & $14.63 \pm 1.51^{b}$ \\
\hline & PBS group 2 & $10.71 \pm 2.29^{\mathrm{a}}$ & $14.57 \pm 1.72^{\mathrm{b}}$ & $14.88 \pm 2.42^{\mathrm{b}}$ & & \\
\hline & Pair-sample $t$ test $^{3}$ & $p>0.05$ & $p<0.05$ & $p>0.05$ & & \\
\hline \multirow[t]{3}{*}{ Live litter size } & Challenged group ${ }^{1}$ & $10.25 \pm 2.06^{\mathrm{a}}$ & $12.86 \pm 1.07^{\mathrm{b}}$ & $14.33 \pm 2.08^{b}$ & $13.75 \pm 1.71^{\mathrm{b}}$ & $12.00 \pm 1.41^{\mathrm{ab}}$ \\
\hline & PBS group ${ }^{2}$ & $11.75 \pm 1.26^{\mathrm{a}}$ & $13.57 \pm 2.44^{\mathrm{a}}$ & $14.50 \pm 1.73^{\mathrm{a}}$ & & \\
\hline & Pair-sample $t$ test $^{3}$ & $p>0.05$ & $p>0.05$ & $p>0.05$ & & \\
\hline
\end{tabular}

\footnotetext{
${ }^{1}$ Data are presented as means \pm SD. Means in the same row with no common superscripts differ significantly $(p<0.05)$ among PRV groups.

${ }^{2}$ Data are presented as means \pm SD. Means in the same row with no common superscripts differ significantly $(p<0.05)$ among PBS groups.

${ }^{3} \mathrm{~A}$ paired $t$ test was performed to determine differences in live embryo number and live litter size between the PBS group and the PRV group fed on the same dosage of vitamin E. Paired $t$-test $p$ value represented the difference of means within the same column; $p<0.05$ was considered significant.
}

Table 8. Effects of vitamin E supplement on serum immunoglobulin concentrations.

\begin{tabular}{llccccc}
\hline \multicolumn{2}{l}{ Vitamin E level (mg/kg) } & 0 & 75 & 375 & 750 & 1,500 \\
\hline IgA & Challenged group $^{1}$ & $76.32 \pm 10.13^{\mathrm{a}}$ & $89.68 \pm 19.70^{\mathrm{ab}}$ & $101.72 \pm 15.41^{\mathrm{b}}$ & $72.54 \pm 15.28^{\mathrm{a}}$ & $73.62 \pm 14.37^{\mathrm{a}}$ \\
$(\mu \mathrm{g} / \mathrm{mL})$ & PBS group $^{2}$ & $69.48 \pm 4.81^{\mathrm{a}}$ & $72.72 \pm 12.39^{\mathrm{ab}}$ & $93.48 \pm 20.02^{\mathrm{b}}$ & & \\
& Pair-sample $t$ test $^{3}$ & $p>0.05$ & $p>0.05$ & $p>0.05$ & & \\
$\mathrm{IgM}$ & Challenged group $^{1}$ & $210.63 \pm 28.22^{\mathrm{a}}$ & $237.96 \pm 34.91^{\mathrm{a}}$ & $313.64 \pm 56.51^{\mathrm{b}}$ & $217.62 \pm 36.51^{\mathrm{a}}$ & $219.69 \pm 47.25^{\mathrm{a}}$ \\
$(\mu \mathrm{g} / \mathrm{mL})$ & PBS group $^{2}$ & $173.90 \pm 26.47^{\mathrm{a}}$ & $192.72 \pm 19.38^{\mathrm{a}}$ & $239.15 \pm 24.08^{\mathrm{b}}$ & & \\
& Pair-sample $t$ test $^{3}$ & $p>0.05$ & $p>0.05$ & $p<0.05$ & & \\
$\mathrm{IgG}$ & Challenged group $^{1}$ & $173.66 \pm 29.16^{\mathrm{a}}$ & $194.82 \pm 21.72^{\mathrm{ab}}$ & $233.91 \pm 38.48^{\mathrm{bc}}$ & $242.92 \pm 26.79^{\mathrm{b}}$ & $184.96 \pm 27.86^{\mathrm{ac}}$ \\
$(\mu \mathrm{g} / \mathrm{mL})$ & PBS group $^{2}$ & $167.42 \pm 28.91^{\mathrm{a}}$ & $186.52 \pm 28.00^{\mathrm{a}}$ & $212.83 \pm 27.7^{\mathrm{a}}$ & & \\
& Pair-sample $t$ test $^{3}$ & $p>0.05$ & $p>0.05$ & $p>0.05$ & &
\end{tabular}

\footnotetext{
${ }^{1}$ Data are presented as means \pm SD. Means in the same row with no common superscripts differ significantly $(p<0.05)$ among PRV groups.

${ }^{2}$ Data are presented as means \pm SD. Means in the same row with no common superscripts differ significantly $(p<0.05)$ among PBS groups.

${ }^{3}$ A paired $t$ test was performed to determine differences in serum immunoglobulin concentration between the PBS group and the PRV group fed on the same dosage of vitamin E. Paired $t$-test $p$ value represented the difference of means within the same column; $p<0.05$ was considered significant.
}

infected mice or PBS-treated mice are shown in Tables 3, 4 and 5. The concentration of $\alpha$-tocopherol increased with increasing vitamin E levels in the diet. Compared to the control groups fed on the same vitamin E dosage, PRV-infected mice had a lower $(p<0.05) \alpha$-tocopherol concentration in serum, liver and uterus, suggesting that vitamin E requirement should be increased for the function of immune system against PRV infection in pregnant mice.

Vitamin E supplements improved reproductive performance

Vitamin E supplements resulted in a tendency to decrease mortality and abortion rates in PRV-challenged mice (Table 6). For example, the mortality and abortion rate in the vitamin E deficienct $(0 \mathrm{mg} / \mathrm{kg})$ PRV group was about 5 to 8 times that observed in the $1,500 \mathrm{mg} / \mathrm{kg}$ PRV group, indicating the positive effect of high level of dietary vitamin $\mathrm{E}$ on disease resistance against PRV infection in pregnant mice.

The lowest live litter size and live embryo number on the 9th day of pregnancy were observed in PRV-challenged mice fed on the vitamin $\mathrm{E}$ deficient diet $(0 \mathrm{mg} /$ $\mathrm{kg}$ ) (Table 7). Both live embryo number and live litter 
Table 9. Effects of vitamin E supplement on serum IL-2, IFN- $\gamma$ and IL-10 concentrations.

\begin{tabular}{|c|c|c|c|c|c|c|}
\hline \multicolumn{2}{|c|}{ Vitamin E level (IU/kg) } & 0 & 75 & 375 & 750 & 1,500 \\
\hline IL-2 & Challenged group $^{1}$ & $54.5 \pm 3.95^{\mathrm{a}}$ & $53.54 \pm 2.27^{\mathrm{a}}$ & $50.91 \pm 1.29^{\mathrm{ab}}$ & $48.73 \pm 3.66^{\mathrm{b}}$ & $45.41 \pm 3.00^{c}$ \\
\hline$(\mathrm{pg} / \mathrm{mL})$ & $\begin{array}{l}\text { PBS group } \\
\text { Pair-sample } t \text { test }^{3}\end{array}$ & $\begin{array}{c}56.07 \pm 3.57^{b} \\
p>0.05\end{array}$ & $\begin{array}{c}47.98 \pm 1.09^{\mathrm{ab}} \\
p<0.05\end{array}$ & $\begin{array}{c}46.31 \pm 6.94^{\mathrm{a}} \\
p>0.05\end{array}$ & & \\
\hline IFN- $\gamma$ & Challenged group ${ }^{1}$ & $18.83 \pm 1.05^{\mathrm{a}}$ & $17.42 \pm 0.69^{b}$ & $14.91 \pm 0.76^{c}$ & $15.15 \pm 0.41^{\mathrm{c}}$ & $15.70 \pm 0.55^{\mathrm{c}}$ \\
\hline$(\mathrm{pg} / \mathrm{mL})$ & $\begin{array}{l}\text { PBS group }{ }^{2} \\
\text { Pair-sample } t \text { test }^{3}\end{array}$ & $\begin{array}{c}12.97 \pm 0.74^{\mathrm{a}} \\
p<0.05\end{array}$ & $\begin{array}{c}13.53 \pm 0.69^{\mathrm{a}} \\
p<0.05\end{array}$ & $\begin{array}{c}14.34 \pm 0.58^{b} \\
p>0.05\end{array}$ & & \\
\hline IL-10 & Challenged group ${ }^{1}$ & $17.29 \pm 2.77^{\mathrm{a}}$ & $19.92 \pm 2.83^{\mathrm{ac}}$ & $22.53 \pm 2.19^{b c}$ & $21.24 \pm 3.18^{\mathrm{ac}}$ & $18.03 \pm 2.46^{\mathrm{a}}$ \\
\hline$(\mathrm{pg} / \mathrm{mL})$ & PBS group $^{2}$ & $18.11 \pm 2.03^{\mathrm{a}}$ & $21.18 \pm 2.61^{\mathrm{a}}$ & $22.71 \pm 3.61^{\mathrm{a}}$ & & \\
\hline & Pair-sample $t$ test $^{3}$ & $p>0.05$ & $p>0.05$ & $p>0.05$ & & \\
\hline
\end{tabular}

\footnotetext{
${ }^{1,2}$ Data are presented as means \pm SD. Means in the same row with no common superscripts differ significantly $(p<0.05)$ among PRV groups.

${ }^{2}$ Data are presented as means \pm SD. Means in the same row with no common superscripts differ significantly $(p<0.05)$ among PBS groups.

${ }^{3} \mathrm{~A}$ paired $t$ test was performed to determine differences in serum cytokine concentration between the PBS group and the PRV group fed on the same dosage of vitamin E. Paired $t$-test $p$ value represented the difference of means within the same column; $p<0.05$ was considered significant.
}

size in PRV-infected mice increased with increasing levels of vitamin E. Live embryo number in PBS groups also increased with vitamin E supplementation. Regression analysis revealed that there was a significant correlation $\left(p<0.05, R^{2}=0.5071\right)$ between dietary vitamin $\mathrm{E}$ level $\left(x, \times 10^{3} \mathrm{IU} / \mathrm{kg}\right)$ and live embryo number $(y)$ on the 9th day of pregnancy following PRV challenge. According to the regression equation $\left(y=-5 \times 10^{-6} x^{2}\right.$ $+0.00987 x+10.319), 987 \mathrm{mg} / \mathrm{kg}$ of dietary vitamin $\mathrm{E}$ is required for pregnant mice to produce the maximal number of live embryos. Similarly, to obtain the maximal live litter size $(y)$, dietary vitamin E requirement $(x)$ by pregnant mice is estimated to be $790 \mathrm{mg} / \mathrm{kg}$ $\left(y=-5 \times 10^{-6} x^{2}+0.0079 x+11.48, R^{2}=0.5516\right)$. The higher vitamin $\mathrm{E}$ requirement by PRV-challenged mice to obtain a live litter size similar to that of PBS-injected mice suggested the importance of vitamin E for embryonic development and fetal health after PRV infection. Effects of vitamin $E$ on serum immunoglobulins

Serum IgG, IgA and IgM concentrations in PBS groups and PRV groups are shown in Table 8. Mice receiving vitamin $\mathrm{E}$ at $375 \mathrm{mg} / \mathrm{kg}$ diet had the highest serum IgA and IgM concentrations in both PBS and PRV groups. There was no difference for serum immunoglobulins concentrations between PBS groups and PRV groups fed on the same vitamin E level with the exception of IgM in the $375 \mathrm{mg} / \mathrm{kg}$ group. For the PRVchallenged mice, the highest serum IgG concentration was observed in the $750 \mathrm{mg} / \mathrm{kg}$ group. In contrast, vitamin E supplement did not affect $(p>0.05)$ the serum IgG concentration in the control mice (PBS-injected).

Vitamin E supplements influenced serum cytokine secretion

In PRV-challenged mice, vitamin E supplement resulted in decreased $(p<0.05)$ concentrations of serum IFN- $\gamma$ and IL-2 (Table 9). In PBS-treated mice, serum IL-2 concentration was also decreased $(p<0.05)$ by vitamin E supplement. In contrast, concentration of serum IL-10 in PRV-challenged mice increased with vitamin E supplements with the highest concentration
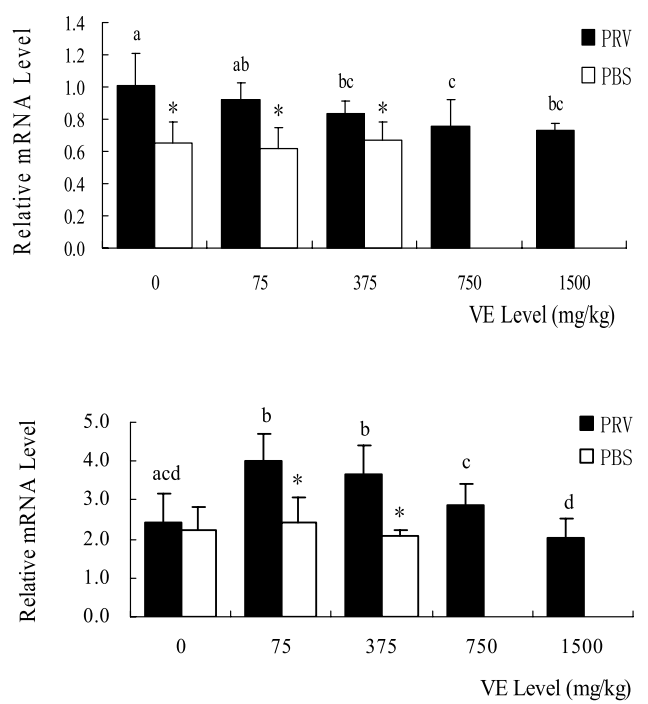

Fig. 2. Relative mRNA abundance of TLR3 in the uterus (A) and embryos (B) of PBS-injected mice compared with that of PRV-injected mice receiving the same or different vitamin E dosage. The mRNA abundance, measured by Real-time RT-PCR, is expressed relative to $\beta$-actin. Data are the mean \pm SD. Different small letters denote statistical differences $(p<0.05)$ among PRV groups. Asterisk $(*)$ denotes statistical differences $(p<0.05)$ between PRV groups and PBS groups fed on the same vitamin $\mathrm{E}$ level according to the paired $t$ test analytical results.

observed in $375 \mathrm{mg} / \mathrm{kg}$ group. Concentrations of serum IL-2 and IFN- $\gamma$ in mice fed on vitamin E at $75 \mathrm{mg} / \mathrm{kg}$ diet was higher $(p<0.05)$ in the PRV group than in the PBS group, but there was no difference $(p>0.05)$ between the PRV group and the PBS group fed vitamin $\mathrm{E}$ at $375 \mathrm{mg} / \mathrm{kg}$ diet. These results indicate the significance of vitamin E supplements in attenuating Th1 cytokine synthesis but promoting Th2 cytokine synthe- 

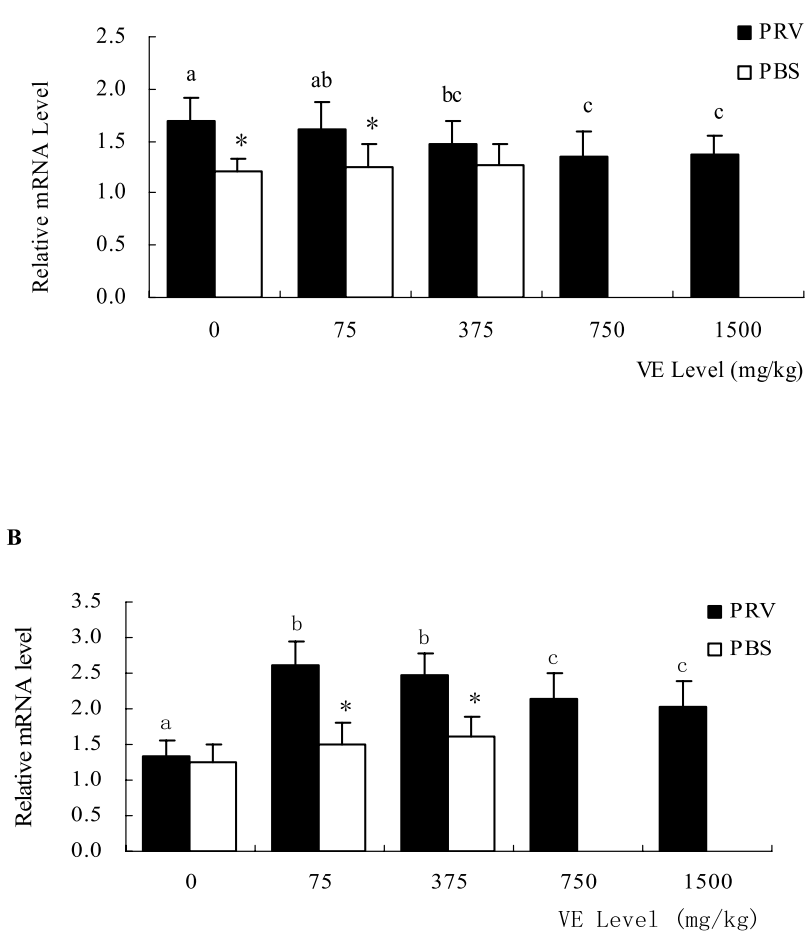

Fig. 3. Relative mRNA abundance of TLR 7 in the uterus (A) and embryos (B) of PBS-injected mice compared with that of PRV-injected mice receiving the same or different vitamin $\mathrm{E}$ dosage. The mRNA abundance, measured by Real-time RT-PCR, is expressed relative to $\beta$-actin. Data are the mean \pm SD. Different small letters denote statistical differences $(p<0.05)$ among PRV groups. Asterisk $(*)$ denotes statistical differences $(p<0.05)$ between PRV groups and PBS groups fed on the same vitamin $\mathrm{E}$ level according to the paired $t$ test analytical results.

sis of PRV-challenged mice.

TLR 3, TLR 7 and TLR 9 expression in uteri and embryos

Relative expression of TLR3, TLR7 and TLR9 in the uterus and embryos is shown in Fig. 2-4. The mRNA abundance of TLR3, TLR7 and TLR9 in the uterus and embryos of PRV-challenged mice was higher $(p<0.05)$ than that of PBS-treated mice fed on the same vitamin E level, indicating that PRV challenge promotes TLR expression. In contrast, vitamin $\mathrm{E}$ supplementation resulted in decreased $(p<0.05)$ mRNA abundance of TLR3, TLR7 and TLR9 in the uterus of PRV-challenged mice, suggesting that the attenuation effect of vitamin $\mathrm{E}$ supplementation on PRV-induced TLR expression. Interestingly, PRV-challenged mice with dietary vitamin E supplementation at $75-375 \mathrm{mg} / \mathrm{kg}$ had a higher mRNA abundance of TLR3, TLR7 and TLR9 in embryos than those fed a vitamin $\mathrm{E}$ deficient diet.

\section{DISCUSSION}

In the present study, serum, hepatic and uterine $\alpha$ tocopherol concentration either in PBS- or PRV-injected mice increased with increasing levels of dietary vitamin E. However, higher improvement was observed in PBS groups rather than PRV groups. For example, supplementation of vitamin $\mathrm{E}$ to the diet at $75 \mathrm{mg} / \mathrm{kg}$ resulted

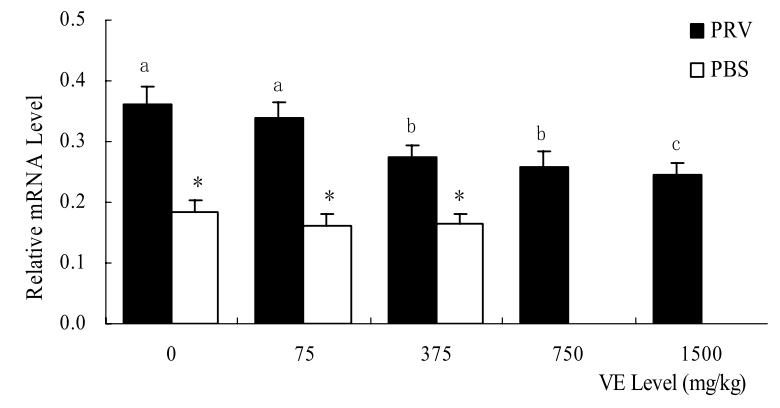

B

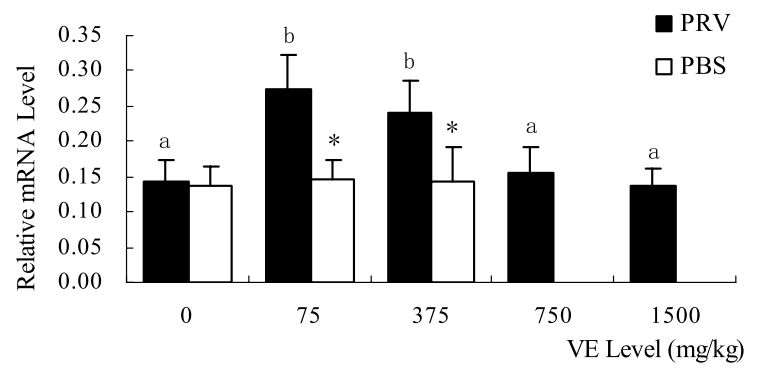

Fig. 4. Relative mRNA abundance of TLR9 in the uterus (A) and embryos (B) of PBS-injected mice compared with that of PRV-injected mice receiving the same or different vitamin E dosage. The mRNA abundance, measured by Real-time RT-PCR, is expressed relative to $\beta$-actin. Data are the mean \pm SD. Different small letters denote statistical differences $(p<0.05)$ among PRV groups. Asterisk $\left(^{*}\right)$ denotes statistical differences $(p<0.05)$ between PRV groups and PBS groups fed on the same vitamin $\mathrm{E}$ level according to the paired $t$ test analytical results.

in two-fold change of the concentration of hepatic $\alpha$ tocopherol in the PRV-challenged mice, whereas fivefold change of the concentration of hepatic $\alpha$-tocopherol in the PBS groups was observed when vitamin E was supplemented at a dose of $75 \mathrm{mg} / \mathrm{kg}$ to the diet. The relatively lower response of serum, hepatic and uterine $\alpha$-tocopherol content in PRV-injected mice may imply the negative effect of PRV challenge on vitamin E utilization of pregnant mice. Decreased $\alpha$-tocopherol concentration was also observed under disease conditions in previous studies $(29,30)$. These results suggest that dietary vitamin E supplement may attenuate PRVinduced negative effects. This concept is further supported by the decreased embryonic mortality in pregnant mice fed on high levels of dietary vitamin $\mathrm{E}$. The death time, 3-7 d after PRV challenge, was the key phase of embryo implantation. In early pregnancy, the immune function was decreased for successful implantation, but it was not beneficial for protecting against viral infections. Vitamin E deficiency also decreased the immune function of animals (31) and thus resulted in an increased sensitivity to viral infections (32). Previous evidence has demonstrated that vitamin E storage in animals decreases when the animal is exposed to a pathologic state $(29,30)$. In this study, the $\alpha$-tocopherol 
concentration in serum, liver and uterus increased with increasing vitamin E levels. The $\alpha$-tocopherol transfer protein $(\alpha$-TTP) is a critical regulator of vitamin E status that stimulates the movement of vitamin $\mathrm{E}$ in different tissues (33). Alpha-TTP is expressed in the uterus and $\alpha$-TTP null mice have a systemic $\alpha$-tocopherol deficiency (34). As a result, the embryos in the uteri of $\alpha$ TTP $-/-$ mutants showed developmental failure from $10.5 \mathrm{~d}$ postcoitum (35). Higher level of $\alpha$-tocopherol may promote the transport of $\alpha$-tocopherol to the uterus and placenta during embryogenesis, which may compensate for vitamin E loss caused by infections. A previous study also reported that high-level vitamin $\mathrm{E}$ supplementation in infected mice could reverse immune function disorders caused by retrovirus infection as well as promoting recovery of infected mice (36). It was reported that vitamin E supplement increased the survival rate of mice infected with type I Diplococcus lanceolatus from 15 to $70 \%$ (37).

The oxidative stress in the female genital duct has been implicated in infertility and can cause endometriosis, abortions, acephalocystis racemosa and implantation failures (38). Vitamin $\mathrm{E}$ is one of the natural antioxidants that have been shown to reduce damage caused by oxidative stress as well as maintaining the integrity of the endometrium (13). Vitamin $\mathrm{E}$ is directly involved in pregnancy establishment. Jishage et al. demonstrated that $\alpha$-tocopherol was indispensable for the proliferation and/or function of the placenta but not necessary for the development of the embryo itself (12). In the present study, increased live embryo number on the 9th day of pregnancy and enhanced live litter size were observed with the increasing of dietary vitamin $\mathrm{E}$ levels. It was also found that the live embryo number was lower in PRV-challenged mice than in PBS-treated mice when fed on vitamin $\mathrm{E}$ at $75 \mathrm{mg} / \mathrm{kg}$ diet, but the live embryo number didn't differ between PRV-challenged and PBS-treated mice when fed on vitamin $\mathrm{E}$ at $375 \mathrm{mg} / \mathrm{kg}$ diet. It was inferred that a higher amount of vitamin E may be required by PRV-challenged mice to maintain normal reproductive performance, which is in agreement with previous reports in swine (39) and cows (40).

Generally, factors elevating the Th1/Th2 ratio may cause early embryo loss $(8,9)$. In contrast, a bias of the Th1/Th2 balance towards Th2 direction has been implicated in successful pregnancy in rodents. The observation that PRV-challenge induced Th1 cytokine (including IL-2 and IFN- $\gamma$ ) synthesis was consistent with previous reports $(8,9,21)$. As expected, vitamin $\mathrm{E}$ supplement indicated an attenuation effect on PRV infection-caused decrease in live embryo number and live litter size. One possible explanation was that vitamin E supplementation could alter expression of genes associated with the cell cycle and the Th1/Th2 balance (14). In support of this view, compared with PRV-challenged mice fed on vitamin E deficiency diet, mice fed on vitamin $\mathrm{E}$ at $375 \mathrm{mg} / \mathrm{kg}$ diet had a lower IFN- $\gamma$ and higher IF-10 concentrations. It was also reported that vitamin E supplementation reduced the risk of acquiring upper respiratory infection in the elderly (41) and influenza infection in aged mice (15). In addition, Th1/Th2 balance may be regulated by sex hormones. Progesterone promoted Th2 cytokine synthesis and inhibited Th1 cytokine synthesis (42). The increased progesterone secretion after vitamin E supplementation (43) may in part account for the increased live embryos and live litter size. In contrast, the observation that oral administration of pharmacological doses of vitamin E (104$198 \mathrm{mg} / \mathrm{kg} \cdot \mathrm{BW} \cdot \mathrm{d}$ ) reduced reproductive fitness and impaired the ovarian functions of female mice (44) may provide another explanation for the decreased live embryo number and live litter size caused by excessive amount of vitamin E supplement.

Serum immunoglobulin concentration reflects the level of humoral immunity in animals. During pregnancy, humoral immunity plays an important role in the protection against viral infections. In this study, serum immunoglobulin concentration increased with increasing dietary vitamin E levels from 0 to $375 \mathrm{mg} /$ kg. Previous studies demonstrated that vitamin E could elevate the primary response in lambs to parainfluenza virus infection (45) as well as increasing passive transport of immunoglobulins in influenza virus-infected mice (46). High immunoglobulin level could result in decreased virus load in the tissue of pregnant mice (47). Meanwhile, repeated intravenous injection of immunoglobulins to post-abortion women infected by dermatitis glandularis erythematosa improved antibody and normal pregnancy results (48). Vitamin E deficiency increased virulence of coxsackievirus b3 in mice due to the phenotype change seen in the CVB3/0 virus (from avirulent to virulent) (18). The most likely explanation is host oxidative stress, which is imposed by the lack of vitamin $\mathrm{E}$ in the diet. This allows accelerated viral replication, which can lead to an increased opportunity for mutations to occur (18). Thus, proper nutrition (vitamin E) aids the host in withstanding and responding to viral infection and may also decrease the opportunity for pathogens to enhance their virulence by mutation.

Pregnancy is a unique immunological challenge in which an antigenically distinct fetus and placenta develop in the uterus of the mother (2). Rapid innate immune defense against infection usually involves the recognition of invading pathogens by specific pattern recognition receptors, which have been recently attributed to the TLR family (49). The results indicated that TLR3, TLR7 and TLR9 were all expressed both in the uterus and in the embryos of mice on the 9th day of pregnancy following either PRV or PBS injection. This finding is consistent with the results of a previous study (50). Between mice fed on the same dosage of vitamin $\mathrm{E}$, PRV-challenged mice showed higher expression of TLR3, TLR7 and/or TLR9 in the uterus and embryo than PBS-injected mice, indicating the significant role of PRV-invasion in inactivating TLR signaling. In the uterus, TLR3, TLR7 and/or TLR9 expression decreased with increasing dietary vitamin E levels, which was similar to Th1 cytokines secretion. This suggests that the appropriate level of vitamin E supplementation may 
down-regulate the expression of TLR3, TLR7 and TLR9, attenuate inflammatory responses and promote pregnancy success of PRV-infected mice. Previous studies indicate that TLR3 participates in polyinosinic-polycytidylic acid (poly I:C)-induced embryo reabsorption by activation of NK cells infiltrated at the fetal-maternal interface (7). Poly I:C (TLR3 agonist) treatment increased fetal losses to $40.2 \pm 1.7 \%$ at midgestation stage compared with control $\mathrm{CBA} \times \mathrm{DBA} / 2$ mice (51). Expression level of TLR3 and TLR9 in endometrial tissues varied in a similar pattern during the menstrual cycle. The levels were high in the perimenstrual period and low in the periovulatory period, which implies that differential spatio-temporal expression patterns of TLRs subserve proper innate immunity of the endometrium $(49,52)$. Overexpression of TLR may be the reason for the highest abortion rates and the lowest live embryo number and live litter size in vitamin E-deficienct mice.

Interestingly, the present study showed that vitamin E had different influences on TLR expression in embryos and uteri. Because there is a low placental transfer of $\alpha$ tocopherol from the maternal blood to the developing fetus (39), the influence of vitamin $\mathrm{E}$ in embryos may differ from that in uteri. TLR3-9 expression changes throughout the embryonic development, which suggests an important role of TLRs in the embryonic development in Drosophila Tolls (53). PRV challenge may increase the requirement of vitamin $\mathrm{E}$ by the maternal immune system, and thus decrease transfer of $\alpha$-tocopherol to the developing fetus.

Conclusively, this study provided the first evidence that PRV challenge resulted in increased vitamin $\mathrm{E}$ requirement by pregnant mice. Appropriate vitamin $\mathrm{E}$ supplement may improve reproductive performance of PRV-challenged pregnant mice via regulating TLR expression and cytokine synthesis and affecting the concentration of immunoglobulins which are beneficial for the embryonic development and resistance to viral infections.

\section{Acknowledgments}

This work was supported by the fund for Innovative Research Team in Universities of China (IRT0555). We would like to thank the staff at our laboratory for their ongoing assistance.

\section{REFERENCES}

1) Challis JR, Lockwood CJ, Myatt L, Norman JE, Strauss JF, Petraglia F. 2009. Inflammation and pregnancy. Reprod Sci 16: 206-215.

2) Guerin LR, Prins JR, Robertson SA. 2009. Regulatory Tcells and immune tolerance in pregnancy: a new target for infertility treatment? Hum Reprod Update 15: 517535.

3) Dealtry GB, O'Farrell MK, Fernandez N. 2000. The Th2 cytokine environment of the placenta. Int Arch Allergy Immunol 123: 107-119.

4) Knackstedt MK, Zenclussen AC, Hertwig K, Hagen E, Dudenhausen JW, Clark DA, Arck PC. 2003. Th1 cytokines and the prothrombinase fgl2 in stress-triggered and inflammatory abortion. Am J Reprod Immunol 49:
210-220.

5) Wegmann TG, Lin H, Guilbert L, Mosmann TR. 1993. Bidirectional cytokine interactions in the maternal-fetal relationship: is successful pregnancy a TH2 phenomenon? Immunol Today 14: 353-356.

6) Mueller T, Terada T, Rosenberg IM, Shibolet O, Podolsky DK. 2006. Th2 cytokines down-regulate TLR expression and function in human intestinal epithelial cells. $J$ Immunol 176: 5805-5814.

7) Lin Y, Liang Z, Chen Y, Zeng Y. 2006. TLR3-involved modulation of pregnancy tolerance in double-stranded RNA-stimulated NOD/SCID mice. J Immunol 176: 4147-4154.

8) Clark DA, Blois S, Kandil J, Handjiski B, Manuel J, Arck PC. 2005. Reduced uterine indoleamine 2,3-dioxygenase versus increased TH1/TH2 cytokine ratios as a basis for occult and clinical pregnancy failure in mice and humans. Am J Reprod Immunol 54: 203-216.

9) Chaouat G, Ledée-Bataille N, Dubanchet S, Zourbas S, Sandra O, Martal J. 2004. TH1/TH2 paradigm in pregnancy: paradigm lost? Cytokines in pregnancy/early abortion: reexamining the TH1/TH2 paradigm. Int Arch Allergy Immunol 134: 93-119.

10) Coquette A, Vray B, Vanderpas J. 1986. Role of vitamin $\mathrm{E}$ in the protection of the resident macrophage membrane against oxidative damage. Arch Int Physiol Biochim 94: S29-34.

11) Cederberg J, Siman CM, Eriksson ULFJ. 2001. Combined treatment with vitamin $\mathrm{E}$ and vitamin $\mathrm{C}$ decreases oxidative stress and improves fetal outcome in experimental diabetic pregnancy. Pediatr Res 49: 755-762.

12) Jishage K, Tachibe T, Ito T, Shibata N, Suzuki S, Mori T, Hani T, Arai H, Suzuki H. 2005. Vitamin E is essential for mouse placentation but not for embryonic development itself. Biol Reprod 73: 983-987.

13) Guney M, Oral B, Demirin H, Ozguner M, Take G, Mungan T, Altuntas I. 2007. Evaluation of caspase-dependent apoptosis during methyl parathion-induced endometrial damage in rats: Ameliorating effect of vitamins E and C. Environ Toxicol Pharmacol 23: 221-227.

14) Han SN, Adolfsson O, Lee CK, Prolla TA, Ordovas J, Meydani SN. 2006. Age and vitamin E-induced changes in gene expression profiles of $\mathrm{T}$ cells. J Immunol 177: 6052-6061.

15) Han SN, Wu D, Ha WK, Beharka A, Smith DE, Bender BS, Meydani SN. 2000. Vitamin E supplementation increases $\mathrm{T}$ helper 1 cytokine production in old mice infected with influenza virus. Immunology 100: 487493.

16) Malmberg KJ, Lenkei R, Petersson M, Ohlum T, Ichihara F, Glimelius B, Frödin JE, Masucci G, Kiessling R. 2002. A short-term dietary supplementation of high doses of vitamin $\mathrm{E}$ increases $\mathrm{T}$ helper 1 cytokine production in patients with advanced colorectal cancer. Clin Cancer Res 8: 1772-1778.

17) Odeleye OE, Eskelson CD, Mufti SI, Watson RR. 1992. Vitamin E protection against nitrosamine-induced esophageal tumor incidence in mice immunocompromised by retroviral infection. Carcinogenesis 13: 18111816.

18) Beck MA, Kolbeck PC, Rohr LH, Shi Q, Morris VC, Levander OA. 1994. Vitamin E deficiency intensifies the myocardial injury of coxsackievirus B3 infection of mice. J Nutr 124: 345-358.

19) Mateusen B, Van Soom A, Maes DG, Favoreel H, Nauw- 
ynck HJ. 2007. Receptor-determined susceptibility of preimplantation embryos to pseudorabies virus and porcine reproductive and respiratory syndrome virus. Biol Reprod 76: 415-423.

20) Tanaka S, Mannen K. 2008. Pregnancy and parturition of mice latently infected with Pseudorabies virus. Exp Anim 57: 149-152.

21) Bianchi ATJ, Moonen-Leusen HWM, van Milligen FJ, Savelkoul HFJ, Zwart RJ, Kimman TG. 1998. A mouse model to study immunity against pseudorabies virus infection: significance of $\mathrm{CD} 4^{+}$and $\mathrm{CD} 8^{+}$cells in protective immunity. Vaccine 16: 1550-1558.

22) Mosmann TR, Coffman RL. 1989. Th1 and Th2 cells: different patterns of lymphokine. secretion lead to different functional properties. Annu Rev Immunol 7: 145173.

23) Ameho CK, Chen CY, Smith D, Sánchez-Moreno C, Milbury PE, Blumberg JB. 2007. Antioxidant activity and metabolite profile of quercetin in vitamin-E-depleted rats. J Nutr Biochem 19: 467-474.

24) He W, Greenwell RJ, Brooks DM, Calderón-Garcidueñas L, Beall HD, Coffin JD. 2007. Arsenic exposure in pregnant mice disrupts placental vasculogenesis and causes spontaneous abortion. Toxicol Sci 99: 244-253.

25) Vogel FS, Caron L, Flores EF, Weiblen R, Winkelmann ER, Mayer SV, Bastos RG. 2003. Distribution of bovine herpesvirus type 5 DNA in the central nervous systems of latently, experimentally infected calves. J Clin Microbiol 41: 4512-4520.

26) Virelizer JL, Allison AC, Schild GC. 1979. Immune responses to influenza virus in the mouse, and their role in control of the infection. Br Med Bull 35: 65-68.

27) Hatam LJ, Kayden HJ. 1979. A high-performance liquid chromatographic method for the determination of tocopherol in plasma and cellular elements of the blood. $J$ Lipid Res 20: 639-645.

28) Rupérez FJ, Barbas C, Castro M, Martínez S, Herrera E. 1998. Simplified method for vitamin $\mathrm{E}$ determination in rat adipose tissue and mammary glands by high-performance liquid chromatography. J Chromatogr A 823: 483-487.

29) Kwaśniewska A, Tukendorf A, Semczuk M. 1997. Content of alpha-tocopherol in blood serum of human Papillomavirus-infected women with cervical dysplasias. Nutr Cancer 28: 248-251.

30) Rocchi E, Seium Y, Camellini L, Casalgrandi G, Borghi A, D'Alimonte P, Cioni G. 2003. Hepatic tocopherol content in primary hepatocellular carcinoma and liver metastases. Hepatology 26: 67-72.

31) Tanaka J, Fujiwara H, Torisu M. 1979. Vitamin E and immune response I. Enhancement of helper T cell activity by dietary supplementation of vitamin $\mathrm{E}$ in mice. Immunology 38: 727-734.

32) Beck MA, Williams-Toone D, Levander OA. 2003. Coxsackievirus B3-resistant mice become susceptible Se/ vitamin E deficiency. Free Radic Biol Med 34: 12631270 .

33) Manor D, Morley S. 2007. The alpha-tocopherol transfer protein. Vitam Horm 76: 45-65.

34) Vasu VT, Oommen S, Lim Y, Valacchi G, Hobson B, Eirserich JP, Leonard SW, Traber MG, Cross CE, Gohil K. 2010. Modulation of ozone-sensitive genes in alphatocopherol transfer protein null mice. Inhal Toxicol 22: $1-16$.

35) Jishage K, Arita M, Igarashi K, Iwata T, Watanabe M,
Ogawa M, Ueda O, Kamada N, Inoue K, Arai H, Suzuki H. 2001. Alpha-tocopherol transfer protein is important for the normal development of placental labyrinthine trophoblasts in mice. J Biol Chem 276: 16691672.

36) Wang Y, Huang DS, Wood S, Watson RR. 1995. Modulation of immune function and cytokine production by various levels of vitamin E supplementation during murine AIDS. Immunopharmacology 29: 225-233.

37) Heizerling RH, Tengerdy RP, Wick LL, Lueker DC. 1974. Vitamin E protects mice against Diplococcus pneumoniae type I infection. Infect Immun 10: 1292-1295.

38) Agarwal A, Gupta S, Sharma RK. 2005. Role of oxidative stress in female reproduction. Reprod Biol Endocrinol 3: 28 .

39) Mahan DC. 1991. Assessment of the influence of dietary vitamin $\mathrm{E}$ on sows and offspring in three parities: reproductive performance, tissue tocopherol, and effects on progeny. J Anim Sci 69: 2904-2917.

40) LeBlanc SJ, Herdt TH, Seymour WM, Duffield TF, Leslie KE. 2004. Peripartum serum vitamin E, retinol and beta-carotene in dairy cattle and their associations with disease. J Dairy Sci 87: 609-619.

41) Meydani SN, Leka LS, Fine BC, Dallal GE, Keusch GT, Singh MF, Hamer DH. 2004. Vitamin E and respiratory tract infections in elderly nursing home residents: a randomized controlled trial. JAMA 292: 828-836.

42) Luchetti CG, Mikó E, Szekeres-Bartho J, Paz DA, Motta AB. 2008. Dehydroepiandrosterone and metformin modulate progesterone-induced blocking factor (PIBF), cyclooxygenase 2 (COX2) and cytokines in early pregnant mice. J Steroid Biochem Mol Biol 111: 200-207.

43) Blois SM, Joachim R, Kandil J, Margni R, Tometten M, Klapp BF, Arck PC. 2004. Depletion of $\mathrm{CD}^{+}$cells abolishes the pregnancy protective effect of progesterone substitution with dydrogesterone in mice by altering the Th1/Th2 cytokine profile. J Immunol 172: 5893-5899.

44) Tarin JJ, Perez Albala S, Pertusa JF. 2002. Oral administration of pharmacological doses of vitamin $\mathrm{C}$ and $\mathrm{E}$ reduces reproductive fitness and impairs the ovarian functions of female mice. Theriogenology 57: 15391550 .

45) Reffett JK, Spears JW, Brown Jr TT. 1988. Effect of dietary selenium and vitamin $\mathrm{E}$ on the primary and secondary immune response in lambs challenged with parainfluenza3 virus. J Anim Sci 66: 1520-1528.

46) Virelizer JL, Virelizer AM, Allison AC. 1976. The role of circulating interferon in the modifications of immune responsiveness by mouse hepatitis virus (MHV-3). J Immunol 117: 748-753.

47) Burgos JS, Ramirez C, Brachet A. 2007. Changes in immunoglobulin levels related to herpes simplex virus type 1 brain infection in pregnant mice. J Neurovirol 13: 233-241.

48) Perricone R, De Carolis C, Kröegler B, Greco E, Giacomelli R, Cipriani P, Fontana L, Perricone C. 2008. Intravenous immunoglobulin therapy in pregnant patients affected with systemic lupus erythematosus and recurrent spontaneous abortion. Rheumatology 47: 646-651.

49) Aflatoonian R, Fazeli A. 2008. Toll-like receptors in female reproductive tract and their menstrual cycle dependent expression. J Reprod Immunol 77: 7-13.

50) Gonzalez JM, Xu H, Ofori E, Elovitz MA. 2007. Toll-like receptors in the uterus, cervix, and placenta: is preg- 
nancy an immunosuppressed state? Am J Obstet Gynecol 197: 1-6.

51) Zhang J, Wei H, Wu D, Tian Z. 2007. Toll-like receptor 3 agonist induces impairment of uterine vascular remodeling and fetal losses in $\mathrm{CBA} \times \mathrm{DBA} / 2$ mice. J Reprod Immunol 74: 61-67.

52) Hirata T, Osuga Y, Hamasaki K, Hirota Y, Nose E,
Morimoto C, Harada M, Takemura Y, Koga K, Yoshino O. 2007. Expression of toll-like receptors 2, 3, 4, and 9 genes in the human endometrium during the menstrual cycle. J Reprod Immunol 74: 53-60.

53) Kambris Z, Hoffmann JA, Imler JL, Capovilla M. 2002. Tissue and stage-specific expression of the Tolls in Drosophila embryos. Gene Expr Patterns 2: 311-317. 